\title{
INFLUENCE OF JOINT HIPERMOBILITY ON POSTOPERATIVE RESULTS OF KNEE SURGERY
}

\section{INFLUÊNCIA DE HIPERMOBILIDADE ARTICULAR NO RESULTADO PÓS-OPERATÓRIO DE CIRURGIA DO JOELHO}

\author{
Diego Costa Astur ${ }^{1}$, Paulo Henrique Schmidt Lara ${ }^{1}$, Marcelo Abdulklech Santos ${ }^{1}$, Gabriel Taniguti de Oliveira ${ }^{1}$, \\ Gustavo Gonçalves Arlanil ${ }^{1}$, Molsés Cohen ${ }^{1}$
}

1. Center for Sports Traumatology, Department of Orthopedics and Traumatology, Universidade Federal de São Paulo, São Paulo, SP, Brazil.

\section{ABSTRACT}

Objective: To evaluate the prevalence of joint hypermobility in patients undergoing knee surgery to treat traumatic injury to the meniscus and anterior cruciate ligament, and the influence of this hypermobility on postoperative results. Methods: This prospective study assessed joint hypermobility in patients who underwent surgical reconstruction of the anterior cruciate ligament $(A C L)$, partial meniscectomy, or a procedure combining $\mathrm{ACL}$ reconstruction and partial meniscectomy during the period 2011-2015. The Beighton score was used to evaluate joint hypermobility and Tegner activity scale for postoperative assessment. Results: A total of 242 patients underwent surgery during the study period: 107 to treat $A C L$ injuries, 75 to treat ACL injuries associated with meniscus injuries, and 60 to treat meniscus injuries. Of the total, 45 patients had joint hypermobility. We found no association between joint hypermobility and sex or type of injury. Postoperative Tegner scale results were not influenced by the presence of joint hypermobility. Conclusion: No association was found between joint hypermobility and the evaluated variables (gender and type of specific injury), and hypermobility did not have a negative impact on postoperative outcomes. Level of Evidence IV; Case series.

Keywords: Knee. Anterior cruciate ligament. Joint instability. Athletic injuries. Sports medicine.

\begin{abstract}
RESUMO
Objetivo: Avaliar a prevalência de hipermobilidade articular em pacientes submetidos à cirurgia do joelho, devido lesão traumática no menisco e ligamento cruzado anterior e a implicação dessa condição física no resultado pós-operatório. Métodos: Estudo prospectivo, no qual pacientes submetidos a cirurgias para reconstrução isolada do ligamento cruzado anterior, reconstrução do ligamento cruzado anterior associada à meniscectomia parcial e meniscectomia parcial isolada de origem traumática durante o período de 2011 a 2015, foram avaliados quanto à presença de hipermobilidade articular. Foram utilizados o Escore de Beighton para avaliar a hipermobilidade articular e a Escala de atividade de Tegner para avaliação pós-operatória. Resultados: Um total de 242 pacientes foram submetidos à cirurgia nesse período (107 devido a lesões do ligamento cruzado anterior, 75 devido a lesões do ligamento cruzado anterior associadas a lesões meniscais e 60 devido a lesões meniscais), sendo que 45 pacientes tinham hipermobilidade articular. Não encontramos associação entre a presença de hipermobilidade articular e um gênero ou tipo específico de lesão. O resultado da Escala de Tegner no pós-operatório não foi influenciado pela presença de hipermobilidade articular nos grupos avaliados. Conclusão: Não encontramos associação entre hipermobilidade articular e um gênero ou tipo de lesão específico nem correlação entre a hipermobilidade articular e resultado pós-operatório pior. Nível de evidência IV; Série de casos.
\end{abstract}

Descritores: Joelho. Ligamento cruzado anterior. Instabilidade articular. Traumatismos em atletas. Medicina esportiva.

Citation: Astur DC, Lara PHS, Santos MA, Oliveira GT, Arliani GG, Cohen M. Influence of joint hipermobility on postoperative results of knee surgery. Acta Ortop Bras. [online]. 2018;26(1):19-21. Available from URL: http://www.scielo.br/aob.

\section{INTRODUCTION}

The anterior cruciate ligament $(\mathrm{ACL})$ and the meniscus are the most commonly injured structures in the knee. ${ }^{1}$ The ACL is an important primary stabilizer; its main function is to restrict anterior translation and internal rotation of the tibia in relation to the femur. ${ }^{2}$ The most important functions of the meniscus are to transmit the load, increase joint cohesion, and distribute the synovial fluid. ${ }^{3}$ Injuries to these structures can consequently cause significant functional deficits.
Several predisposing factors for injury to these structures are known. ${ }^{4}$ Alteration to the mechanical axis of the lower limbs can lead to meniscus injury, and a narrower intercondylar fossa can lead to ACL injuries. ${ }^{5,6}$ The association between ACL rupture and joint hypermobility still remains controversial:;,8 some studies have found higher rates of joint hypermobility in patients with ACL rupture, ${ }^{9-10}$ while others have not. ${ }^{11-12}$ Sueyoshi et $a . .^{13}$ demonstrated that patients with joint hypermobility have a higher risk of knee sprain. There are

All authors declare no potential conflict of interest related to this article.

Work conducted at the Center for Sports Traumatology, Department of Orthopedics and Traumatology, Universidade Federal de São Paulo, São Paulo, SP, Brazil. Correspondence: Paulo Henrique Schmidt Lara. Rua Estado de Israel, 636, Vila Clementino, São Paulo, SP, Brazil. 04022-001. phslara@gmail.com 
several methods to evaluate joint hypermobility; the most common is the Beighton score. ${ }^{14}$

The association between joint hypermobility and isolated meniscus injuries or meniscus injuries associated with ACL injuries has not yet been evaluated. Furthermore, it is not known whether joint hypermobility is associated with any particular type of knee injury or patient sex. The objective of this study was to assess the prevalence of joint hypermobility in patients who underwent knee surgery to treat meniscus and ligament injuries, and the impact of this physical condition on postoperative results.

\section{METHODS}

This research project was approved by the institutional review board at the Escola Paulista de Medicina - UNIFESP (number 01609812.9.0000.5505). This is a prospective study, in which amateur athlete patients who received surgical treatment for the aforementioned knee injuries from 2011 to 2015 were assessed by an orthopedic specialist to determine the presence of joint hypermobility. Inclusion criteria were amateur athletes who received surgical treatment for isolated ACL injuries, isolated meniscus injuries, and ACL injuries associated with traumatic meniscus injuries. Exclusion criteria were the presence of other associated knee injuries and meniscus injuries treated with sutures. All patients signed an informed consent form before participating in the study.

The patients were divided into three groups: isolated ACL injuries, isolated meniscus injuries, and ACL injuries associated with meniscus injuries. The surgical procedures and evaluation of the presence of joint hypermobility were performed by the same surgical team. The Beighton score was used; the maximum value is nine points, and a score greater than or equal to four was considered joint hypermobility. One point is awarded for each positive result in the following tests on each side of the body: passive hyperextension of the fifth metacarpophalangeal joint (greater than 90 degrees), passive apposition of the thumb to the flexor aspect of the forearm, active hyperextension of the forearm (greater than 10 degrees), active hyperextension of the knee (greater than 10 degrees), and active forward flexion of the trunk with the knees fully extended so that the palms of the hands rest flat on the floor. For postoperative evaluation, the Tegner activity scale was used:15 this assessment is composed of eight questions and scores are assigned from 0 to 10, ranging from the patient's inability to perform activities to lack of limitation, respectively. In the patients evaluated in this study, the Tegner scale was applied after treatment of the injury was complete and patients began sports activities, which took an average of 3 months after surgery for meniscus injuries and 6 months after treatment of ACL injuries (whether associated with meniscus injuries or not).

The surgical technique for ACL injuries utilized knee flexor tendons (semitendinosus and gracilis) and absorbable interference screws in the tibia and femur buttons as fixation methods in the anatomical reconstruction technique, in which femoral and tibial bone tunnels are created in the center of the anterior cruciate ligament insertion in these bones. ${ }^{16}$ For cases of meniscus injury, a partial meniscectomy was performed. Rehabilitation for the cases of ACL reconstruction took place in accordance with the Multicenter Orthopedic Outcomes Network (MOON) ACL Rehabilitation Guidelines ${ }^{17}$ and for cases of meniscus injury, patients underwent physical therapy rehabilitation for an average of three months.

\section{Statistical analysis}

Because the data were quantitative and continuous, we utilized statistical parametric tests. To evaluate the qualitative variables, the equality of two proportions test was used. Analysis of variance (ANOVA) was used for comparisons between the groups and sexes in relation to the Beighton score. The Pearson correlation was used to correlate the Beighton score and Tegner scale. A 0.05 (5\%) significant level was adopted. SPSS V17 software (SPSS Inc, Chicago, IL) was used to conduct the analysis.

\section{RESULTS}

During the study period, 242 patients underwent surgery; 107 to treat isolated ACL injuries, 75 for ACL injuries associated with meniscus injuries, and 60 to treat isolated meniscus injuries. Of these patients, 199 were male and 43 were female. The mean patient age was 32.9 years, ranging from 10 to 72 , with a standard deviation (SD) of $11.88(\mathrm{Cl}=1.5)$. The Beighton score ranged from 0 to 9 , with 2 the most prevalent and SD of $2.18(\mathrm{Cl}=0.27)$. The Tegner scale varied from 0 to 10, with 3 the most prevalent, and SD of $1.88(\mathrm{Cl}=0.24)$. There were 45 patients with joint hypermobility according to the study criterion (Beighton score greater than or equal to 4). The sex distribution and presence of joint hypermobility according to injury are shown in Table 1. The ethnic makeup of the study group was 151 white, 63 mixed race of African descent, 25 Black, and 3 Asian. Comparison of the presence or absence of joint hypermobility according to Beighton score in the evaluated groups (isolated ACL injury, isolated meniscus injury, and associated ACL and meniscus injuries) showed no statistically significant difference, with the majority of patients not presenting joint hypermobility $(p<0.001)$. (Table 2) Comparison of the presence or absence of joint hypermobility according to Beighton score in male and female patients also demonstrated no statistically significant difference, with joint hypermobility absent in patients of both sexes $(p<0.001)$. (Table 3 and 4) No significant difference between sexes was seen in the different groups with regard to the presence of joint hypermobility ( $p>0.577)$. (Table 5)

The results for the Tegner scale upon returning to sports was not influenced by the presence or absence of joint hypermobility for the assessed groups ( $p>0.07)$. (Table 6)

Table 1. Sex distribution according to injury and presence of joint hypermobility.

\begin{tabular}{c|c|c|c|c}
\hline & \multicolumn{2}{|c|}{ Men } & \multicolumn{2}{c}{ Women } \\
\hline & $\begin{array}{c}\text { Without } \\
\text { hypermobility }\end{array}$ & $\begin{array}{c}\text { With } \\
\text { hypermobility }\end{array}$ & $\begin{array}{c}\text { Without } \\
\text { hypermobility }\end{array}$ & $\begin{array}{c}\text { With } \\
\text { hypermobility }\end{array}$ \\
\hline ACL & $68(82.9 \%)$ & $14(17.1 \%)$ & $18(85.7 \%)$ & $3(14.3 \%)$ \\
\hline Meniscus & $43(79.6 \%)$ & $11(20.4 \%)$ & $6(100 \%)$ & $0(0 \%)$ \\
\hline ACL + MENISCUS & $47(78.3 \%)$ & $13(21.7 \%)$ & $12(75 \%)$ & $4(25 \%)$ \\
\hline
\end{tabular}

Table 2. Comparison between groups by presence of absence of joint hypermobility.

\begin{tabular}{c|c|c|c|c|c}
\hline & \multicolumn{2}{|c|}{ Without hypermobility } & \multicolumn{2}{c|}{ With hypermobility } & \multirow{2}{*}{ P-value } \\
\cline { 2 - 5 } & $\mathbf{N}$ & $\%$ & $\mathbf{N}$ & $\%$ & \\
\hline ACL & 86 & $83.5 \%$ & 17 & $16.5 \%$ & $<0.001$ \\
\hline ACL + MENISCUS & 59 & $77.6 \%$ & 17 & $22.4 \%$ & $<0.001$ \\
\hline Meniscus & 54 & $83.1 \%$ & 11 & $16.9 \%$ & $<0.001$ \\
\hline
\end{tabular}

Table 3. Comparison between groups, females only, by presence or absence of hypermobility.

\begin{tabular}{c|c|c|c|c|c}
\hline \multirow{2}{*}{ Female } & \multicolumn{2}{|c|}{ With hypermobility } & \multicolumn{2}{l}{ Without hypermobility } & \multirow{2}{*}{ P-value } \\
\cline { 2 - 5 } & $\mathbf{N}$ & $\%$ & $\mathbf{N}$ & $\%$ & \\
\hline ACL & 3 & $14.3 \%$ & 18 & $85.7 \%$ & $<0.001$ \\
\hline ACL + MENISCUS & 4 & $25.0 \%$ & 12 & $75.0 \%$ & $<0.001$ \\
\hline Meniscus & 0 & $0.0 \%$ & 6 & $100 \%$ & $<0.001$ \\
\hline
\end{tabular}

Table 6. Correlation between Beighton score and Tegner scale, by group.

\begin{tabular}{c|c|c}
\hline \multirow{2}{*}{} & \multicolumn{2}{|c}{ Beighton vs. Tegner } \\
\cline { 2 - 3 } & Correlation (r) & P-value \\
\hline ACL & $-17.6 \%$ & 0.070 \\
\hline ACL + Meniscus & $-1.6 \%$ & 0.895 \\
\hline Meniscus & $-6.6 \%$ & 0.615 \\
\hline All & $-9.1 \%$ & 0.160
\end{tabular}


Table 5. Comparison of Beighton scores between sexes for different groups.

\begin{tabular}{c|c|c|c|c|c|c|c|c|c|c}
\hline \multicolumn{2}{c|}{ Beighton } & Mean & Median & $\begin{array}{c}\text { Standard } \\
\text { Deviation }\end{array}$ & CV & Min & Max & N & Cl & \multirow{2}{*}{ P-value } \\
\hline \multirow{2}{*}{ ACL } & Female & 1.81 & 2 & 1.63 & $90 \%$ & 0 & 7 & 21 & 0.70 & \multirow{2}{*}{0.577} \\
\cline { 2 - 13 } & Male & 1.53 & 1 & 2.10 & $137 \%$ & 0 & 10 & 86 & 0.44 & \\
\hline \multirow{2}{*}{ ACL +} & Female & 2.00 & 2 & 1.97 & $98 \%$ & 0 & 7 & 16 & 0.96 & \multirow{2}{*}{0.784} \\
\cline { 2 - 11 } Meniscus & Male & 2.19 & 2 & 2.51 & $115 \%$ & 0 & 8 & 59 & 0.64 & \\
\hline \multirow{2}{*}{ Meniscus } & Female & 1.67 & 2 & 0.52 & $31 \%$ & 1 & 2 & 6 & 0.41 & \multirow{2}{*}{0.785} \\
\cline { 2 - 10 } & Male & 1.93 & 1.5 & 2.29 & $119 \%$ & 0 & 9 & 54 & 0.61 & \\
\hline
\end{tabular}

Table 4. Comparison between groups, males only, by presence or absence of hypermobility.

\begin{tabular}{c|c|c|c|c|c}
\hline \multirow{2}{*}{ Male } & \multicolumn{2}{|c|}{ With hypermobility } & \multicolumn{2}{|c|}{ Without hypermobility } & \multirow{2}{*}{ P-value } \\
\cline { 2 - 5 } & $\mathbf{N}$ & $\%$ & $\mathbf{N}$ & $\%$ & \\
\hline $\mathrm{ACL}$ & 14 & $16.3 \%$ & 72 & $83.7 \%$ & $<0.001$ \\
\hline $\mathrm{ACL}+$ MENISCUS & 13 & $22.0 \%$ & 46 & $78.0 \%$ & $<0.001$ \\
\hline Meniscus & 11 & $20.4 \%$ & 43 & $79.6 \%$ & $<0.001$ \\
\hline
\end{tabular}

\section{DISCUSSION}

Among patients with ACL injuries, we found a prevalence of $17.1 \%$ for joint hypermobility in men and $14.3 \%$ in women, results lower than those found in the literature, which range from 40 to $60 \% .{ }^{19,20}$ Previous studies $^{19,20}$ encountered a higher prevalence of joint hypermobility in women, especially adolescents, compared to men. We also found similar results for the prevalence of joint hypermobility among patients with meniscus injuries and associated ACL/meniscus injuries, but since no studies have performed these assessments, no comparisons could be drawn.

The association between joint hypermobility and ACL injury remains controversial, and may be partly due to inconsistency in evaluating joint hypermobility. ${ }^{8}$ For example, studies consider different cutoff points for the Beighton score which range from 4 to 6 points. Due to differences in the definition and identification of cases, the prevalence of joint hypermobility in adults varies in studies from 5 to $43 \% .^{18}$ In a systematic review performed by Pacey et al., ${ }^{18} 5$ studies described knee injuries and a statistically significant relationship was found between joint hypermobility and greater risk of knee injury. We should note that this study included all knee injuries, not only ACL injuries. In all patient ethnic groups except Asians, more than $80 \%$ of patients did not have joint hypermobility. In the Asian patients in our study, $66.6 \%$ had joint hypermobility, but we should note that there were only 3 patients in this group.

We compared to the presence or absence of joint hypermobility between the sexes for each group, but found no significant difference. Finally, we performed a correlation between the postoperatory Beighton score and Tegner scale in the three study groups (ACL, meniscus, and $\mathrm{ACL} /$ meniscus) to determine whether the presence of joint hypermobility was associated with poorer postoperative results. Although there was no statistical difference (i.e., the variables were independent), the group of patients with isolated ACL injuries presented poorer postoperative results $(p=0.07)$ than the groups with isolated meniscus injury $(p=0.615)$ and $A C L$ injury associated with meniscus injury $(p=0.895)$.

All lesions included in this study were traumatic, but patients aged 10 to 72 years were included; this age difference may have had an influence on the results, and older patients may have had degenerative meniscus injuries prior to the traumatic injury. Furthermore, we do not know if there were changes in joint hypermobility with aging. Risk factors for ligament and meniscus injuries are probably multifactorial, but joint hypermobility may be an important contributor to the stability of the knee and may consequently be a predisposing factor for these injuries.

\section{CONCLUSION}

We did not find any association between joint hypermobility and sex or type of injury evaluated, and did not find a correlation between joint hypermobility and poorer postoperative outcomes.

AUTHORS' CONTRIBUTIONS: Each author made significant individual contributions to this manuscript. DCA (0000-0001-9163-7979)*: performed the surgeries, wrote and reviewed the article; PHSL (0000-0002-1623-2071)*: performed data analysis and statistical analysis and wrote the article; MAS (0000-0003-3899-2175)*: and GTO (0000-0001-6288-6896)*: wrote the article; GTO (0000-0001-6288-6896)* and GGA (0000-0003-4371-5041)*: performed the surgeries and reviewed the article; MC (0000-0001-7671-8113)*: performed the surgeries and contributed to the intellectual concept of the study. *ORCID (Open Researcher and Contributor ID).

\section{REFERENCES}

1. Amis AA, Dawkins GP. Functional anatomy of the anterior cruciate ligament. Fibre bundle actions related to ligament replacements and injuries. J Bone Joint Surg Br. 1991;73(2):260-7

2. Astur DC, Batista RF, Arliani GG, Cohen M. Tendências de tratamento das lesões do ligamento cruzado anterior do joelho nos sistemas de saúde pública e privada do Brasil. São Paulo Med J. 2013:131(4):257-63.

3. Renström P, Johnson RJ. Anatomy and biomechanics of the menisci. Clin Sports Med. 1990;9(3):523-38.

4. Arendt E, Dick R. Knee injury patterns among men and women in collegiate basketball and soccer. NCAA data and review of literature. Am J Sports Med. 1995:23(6):694-701.

5. Habata T, Ishimura M, Ohgushi H, Tamai S, Fujisawa Y. Axial alignment of the lower limb in patients with isolated meniscal tear. J Orthop Sci. 1998;3(2):85-9.

6. Görmeli CA, Görmeli G, Öztürk BY, Özdemir Z, Kahraman AS, Yıldırım O, et al. The effect of the intercondylar notch width index on anterior cruciate ligament injuries: a study on groups with unilateral and bilateral ACL injury. Acta Orthop Belg. 2015;81(2):240-4.

7. Griffin LY, Agel J, Albohm MJ, Arendt EA, Dick RW, Garrett WE, et al. Noncontact anterior cruciate ligament injuries: risk factors and prevention strategies. J Am Acad Orthop Surg. 2000;8(3):141-50.

8. Ramesh R, Von Arx O, Azzopardi T, Schranz PJ. The risk of anterior cruciate ligament rupture with generalised joint J Bone Joint Surg Br. 2005;87(6):800-3.

9. Uhorchak JM, Scoville CR, Williams GN, Arciero RA, St Pierre P, Taylor DC. Risk factors associated with noncontact injury of the anterior cruciate ligament: a prospective four-year evaluation of 859 West Point cadets. Am J Sports Med. 2003;31(6):831-42.

10. Magnussen RA, Reinke EK, Huston LJ; MOON Group, Hewett TE, Spindler KP.
Factors Associated With High-Grade Lachman, Pivot Shift, and Anterior Drawer at the Time of Anterior Cruciate Ligament Reconstruction. Arthroscopy. 2016;32(6):1080-5

11. Kalenak A, Morehouse CA. Knee stability and knee ligament injuries. JAMA 1975;234(11):1143-5

12. Moretz JA, Walters R, Smith L. Flexibility as a predictor of knee injuries in college football players. Phys Sportsmed. 1982;10:93-7

13. Sueyoshi T, Emoto G, Yuasa T. Generalized Joint Laxity and Ligament Injuries in High School-Aged Female Volleyball Players in Japan. Orthop J Sports Med. 2016;4(10): 2325967116667690.

14. Beighton P, Solomon L, Soskolne CL. Articular mobility in an African population. Ann Rheum Dis. 1973;32(5):413-8.

15. Tegner Y, Lysholm J. Rating systems in the evaluation of knee ligament injuries. Clin Orthop Relat Res. 1985;(198):43-9.

16. Brown $\mathrm{CH}$ Jr, Spalding T, Robb C. Medial portal technique for single bundle anatomical anterior cruciate ligament $(A C L)$ reconstruction. Int Orthop. 2013;37(2):253-69.

17. Wright RW, Haas AK, Anderson J, Calabrese G, Cavanaugh J, Hewett TE, et al. MOON Group. Anterior Cruciate Ligament Reconstruction Rehabilitation: MOON Guidelines. Sports Health. 2015;7(3):239-43.

18. Pacey V, Nicholson LL, Adams RD, Munn J, Munns CF. Generalized joint hypermobility and risk of lower limb joint injury during sport: a systematic review with meta-analysis. Am J Sports Med. 2010;38(7):1487-97.

19. Seçkin U, Tur BS, Yilmaz O, Yağci I, Bodur H, Arasil T. The prevalence of joint hypermobility among high school students. Rheumatol Int. 2005:25(4):260-3.

20. Larsson LG, Baum J, Mudholkar GS. Hypermobility: features and differential incidence between the sexes. Arthritis Rheum. 1987:30(12):1426-30. 